\title{
Recorregut de recerca geològica i mineralògica per les comarques del Baix Camp i del Priorat: des de Botarell a Riudecols, al Coll Negre, al Coll de Teixeta i a Pradell de la Teixeta
}

Josep Maria Mata-Perelló

Joaquim Sanz Balagué

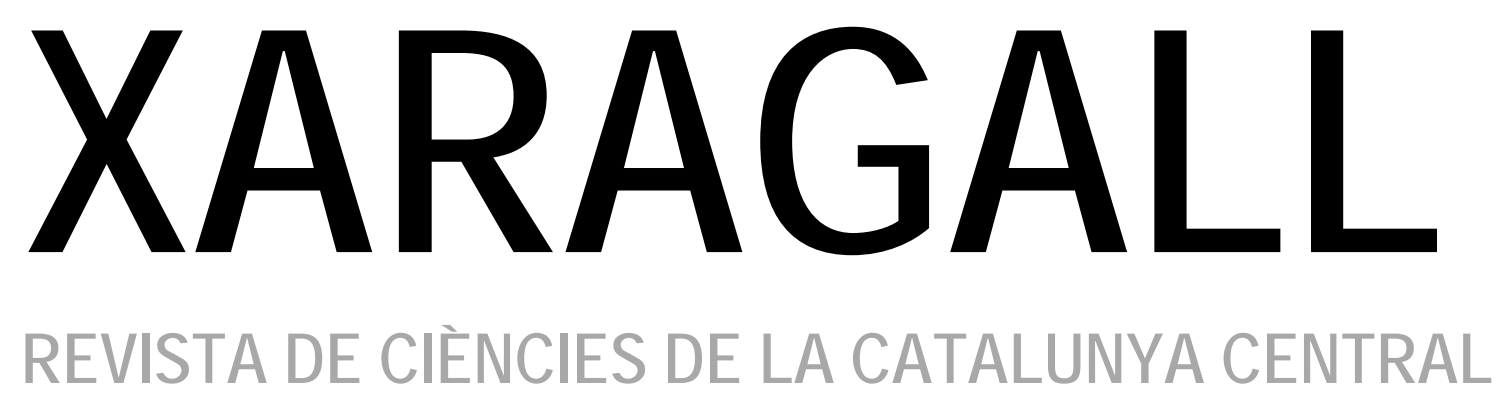

\section{n. 5}

MAIG 2015 


\title{
RECORREGUT DE RECERCA GEOLÒGICA I MINERALÒGICA PER LES COMARQUES DEL BAIX CAMP I DEL PRIORAT: DES DE BOTARELL A RIUDECOLS, AL COLL NEGRE, AL COLL DE TEIXETA I A PRADELL DE LA TEIXETA
}

\author{
Josep Maria Mata-Perelló \\ Museu de geologia Valentí Masachs, Escola Politècnica Superior d'Enginyeria de Manresa \\ (EPSEM), Universitat Politècnica de Catalunya · BarcelonaTech (UPC), 08272 Manresa, Spain
}

\section{Joaquim Sanz Balagué}

Departament d'Enginyeria Minera i Recursos Naturals (EMRN), Escola Politècnica Superior d'Enginyeria de Manresa (EPSEM), Universitat Politècnica de Catalunya - BarcelonaTech (UPC), 08272 Manresa, Spain

Paraules clau: Sistema Mediterrani, Patrimoni miner

\section{Resum}

Itinerari realitzat el 15 de juny de 2014. En aquesta ocasió, el recorregut del present itinerari discorrerà íntegrament, per una sola de les tres unitats geològiques que constitueixen Catalunya: concretament per la coneguda com a Sistema Mediterrani. Dintre d'aquesta, el recorregut recalarà, de forma molt quasi exclusiva per la Serralada Prelitoral Catalana. Molt puntualment, d'una forma totalment marginal, entrarà en la Depressió Prelitoral Catalana, especialment entre Botarell i Riudecols.

Així, el recorregut s'iniciarà dintre de la primera subunitats esmentada, per la qual discorrerà quasi totalment el recorregut. Així, començarà a l'estació de Botarell, dintre de la Serralada Prelitoral Catalana, per on es farà la primera aturada. Després, el recorregut discorrerà pels termes de Riudecols, I'Alforja, Duesaigües, Porrera i Pradell de la Teixeta; finalitzant en aquesta darrera població, dintre de la serralada esmentada en un principi.

Per altra banda, el recorregut començarà a la comarca del Baix Camp, per a finalitzar a la del Priorat. El trànsit de la primera a la segona comarca es farà en passar pel Coll de la Teixeta. 


\section{Objectius fonamentals}

A través d'aquest itinerari geològico-mineralògic, s'intentarà d'aconseguir els següents objectius:

1. Estudi de l'estructura de la Serralada Prelitoral Catalana, las qual es tallarà al llarg de quasi tot el recorregut de l'itinerari entre Botarell (comarca del Baix Camp) i Pradell de la Teixeta (comarca del Priorat).

2. Estudi i reconeixement dels materials que la constitueixen, de la Serralada Prelitoral Catalana, al llarg de tot el recorregut de l'itinerari. Aquests materials es distribueixen entre el Paleozoic (exclusivament del carbonífer, el qual inclou als afloraments de roques ígnies) i el Mesozoic (representat exclusivament pels trams inferior i mig del Triàsic).

3. Observació del contacte entre les dues unitats del Sistema Mediterrani, que trobarem al llarg d'aquest itinerari; és a dir. del contacte entre la Serralada Prelitoral Catalana i la Depressió Prelitoral Catalana. Aquest contacte el passarem en el recorregut de Botarell a Riudecols, de la primera a la segona parada del recorregut de l'itinerari.

4. Estudi de diverses mineralitzacions situades a la Serralada Prelitoral Catalana, que anirem trobant al llarg del recorregut de l’itinerari, com les següents:

4A) les mineralitzacions filonianes de minerals de coure, que trobarem a Riudecols (Baix Camp). Es troben encaixades entre els materials paleozoics del carbonífer.

4B) les mineralitzacions estratiformes associades a "sedex", de $\mathrm{Pb}-\mathrm{Zn}-\mathrm{Cu}$, que trobarem al terme d'Alforja, situades entre afloraments de materials mesozoics de I'Ordovicià.

4C) de les mineralitzacions filonianes de $P b-Z n$, que trobarem al terme de Pradell de la Teixeta, entre els materials paleozoics del Carbonífer.

4D) y de les mineralitzacions evaporítiques, que trobarem a Pradell de la Teixeta, entre els afloraments dels materials triàsics del Keuper.

5. Observació de la tipologia de les explotacions mineres relacionades amb les mineralitzacions acabades d'esmentar.

6. Observació dels elements més importants del Patrimoni Miner i del Patrimoni Geològic relacionats amb les explotacions i amb les mineralitzacions anteriors

7. Observació de les alteracions produïdes sobre el Medi Natural, com a conseqüència de les explotacions mineres acabades d'esmentar; i en tot cas, de la restauració duta a terme. 


\section{Antecedents}

En relació amb el present itinerari, existeix uns antecedents bibliogràfics molt propers i parcials, ja que no existeix cap itinerari que concordi amb el trajecte del que ara presentem. Així, farem esment d'aquests antecedents nostres totalment parcials i puntuals: MATA - PERELLÓ (1994, 1995 i 2014).

Pel que fa a les mineralitzacions, cal fes esment de d'interessant antecedent de MELGAREJO i DRAPER (1992), referit a les comarques reusenques. Un altre antecedent es troba en MATAPERELLÓ (1991), referit a les mineralitzacions del conjunt dels Països Catalans.

Pel que fa als trets de la geologia d'aquestes comarques, ens referirem de nou al treball de MELGAREJO i DRAPER (1992); així com a les publicacions de I'IGME (1974a i 1974b). Per d'altra banda, també farem esment de dos treballs referits al conjunt dels Països Catalans. Es tracta dels de: GUIMERÀ et altri (1992) i de RIBA et altri (1979).

Tots aquests treballs, i d'altres, figuraran per ordre alfabètic dintre de l'apartat dedicat a les REFERĖNCIES BIBLIOGRÀFIQUES.

\section{Recorregut de l'itinerari}

El recorregut del present itinerari començarà a la població de Botarell; concretament a la seva Estació de la RENFE, per on es farà la primera aturada del recorregut d'aquest itinerari. Després, el recorregut es dirigirà cap a la població de Riudecols. Si s'escau, podrà anar-se d'un indret a l'altre, remuntant la riera de Riudecols. També pot anar-se per la carretera de Botarell a les Borges del Camp, fins arribar a la carretera N - 420. En trobar-la, sols caldrà anar cap a ponent, cap a Riudecols.

En arribar a aquesta darrera població esmentada, es realitzaran diverses aturades, entorn a la població. Després, caldrà seguir per la carretera $\mathrm{N}-420$, cap a ponent, per on es farà una nova aturada, després de sobrepassar el poblet de les Irles. Seguidament, caldrà seguir pel tram vell de la carretera $\mathrm{N}-420$, fins trobar el trencall del Mas del Mestre, que ens caldrà agafar per tal d'anar a les Mines del Mas del Mestre, per on farem una nova aturada.

Després, caldrà retornar a la carretera $\mathrm{N}-420$, per tal de continuar cap a ponent. En arribar al Coll de la Teixeta, es farà una nova aturada, continuant el recorregut de l'itinerari cap a ponent, passant de la comarca del Baix Camp a la del Priorat. Després de sobrepassar el trencall de Pradell de la Teixeta i el Coll de Pradell, caldrà fer una fillola per tal d'anar cap a les Mines de Pradell de la Teixeta, per tal de fer una altra aturada.

Finalment, el recorregut es dirigirà cap el poble darrerament esmentat, per tal de fer les darreres aturades a unes antigues explotacions de guix, anant cap el poble de la Torre de la Fontaubella. 


\section{Advertiments previs}

Com en altres recorreguts de RECERCA GEOLÒGICA I MINERALÒGICA... si es disposa del temps suficient, poden efectuar-se passant per totes les parades i filloles. En cas contrari, recomanem prescindir de les anomenades PARADES - CONDICIONALS.

També recomanem de cercar la informació més adient, sobre els trams a recórrer mitjançant camins de terra, o de pista. Precisament, en aquest itinerari, hi ha alguns trajectes d'aproximació cap a les mines, que haurem de fer per camins de terra en irregular estat de conservació. Aquest és el cas de l'accés a les Mines de Collblanc (Riudecols) i a les Mines del Mas del Mestre (Alforja) entre altres indrets del recorregut d'aquest itinerari.

Per altra banda, recomanem tenir una cura extrema de la NATURA, evitant qualsevol forma d'agressió sobre ella, o de fer-n'hi un mal ús del que en ofereix la nostra mare Terra.

\section{Descripció de l'itinerari}

Com de costum, estructurarem el recorregut de l'itinerari en una sèrie de PARADES, que tot seguit anirem veient. En cadascuna d'aquestes aturades farem un breu comentari (geològic 0 mineralògic, segons s'escaigué).

En cada cas indicarem, entre parèntesi el full topogràfic del "Mapa Topogràfico Nacional" a escala 1:50.000 on es troba l'aturada, que en aquest cas serà sempre els fulls números $\mathbf{4 4 5}$ (també dit de Cornudella) i $\mathbf{4 7 2}$ (dita de Reus). Aquests fulls han estat publicats per I'Instituto Geografico y Catastral de España.

Així doncs, la relació ordenada de les aturades que composen el recorregut d'aquest itinerari, és la següent:

\subsection{Parada 1. ESTACIÓ DE LA RENFE A BOTARELL, (terme municipal de Botarell, comarca del Baix Camp). (Full 472).}

El recorregut l'iniciarem a l'Estació de la RENFE a Botarell. En aquest mateix indret, situat a poc més de $2 \mathrm{Km}$ del poble, realitzarem la primera aturada d'aquest itinerari. I l'iniciarem a les andanes de l'Estació.

Aquest indret es troba situat a la Serralada Prelitoral Catalana. En efecte, al marge de la via, al talús, s'observen afloraments dels materials esquistosos del Carbonífer de l'esmentada serralada. (fotografia 1). 


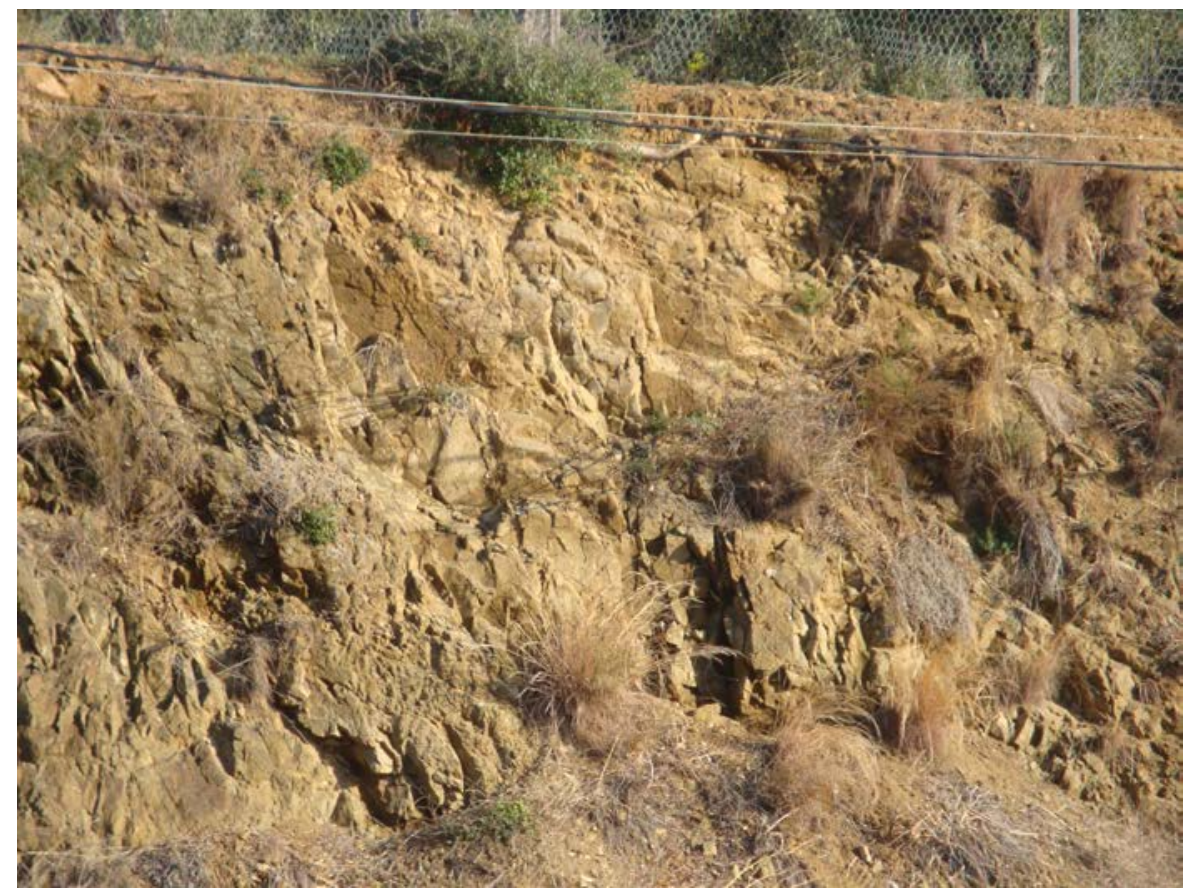

Fotografia 1. Els materials del Carbonífer a l'Estació de la RENFE a Botarell

(Serralada Prelitoral Catalana)

\subsection{Parada 2. FORN D'OBRA DE RIUDECOLS, BÒVILA CASALS, (les Voltes, terme municipal de Riudecols, comarca del Baix Camp). (Full 472).}

Després de realitzar l'aturada anterior, ens caldrà fer un breu recorregut primer cap al poble de Botarell i posteriorment cap a les Borges del Camp. Per anar-hi, cal agafar a Botarell la carretera $T-320$, la qual ens durà a la ruta $N-420$. En arribar a aquesta ruta, ens caldrà agafar-la en el seu sentit ponentí (cap a Falset). Així, aviat arribarem al llogarret de les Voltes. Poc després, ens caldrà fer una aturada al costat de la carretera, a ma dreta segons el nostre sentit de la marxa. Així, haurem efectuat un recorregut molt proper als $6 \mathrm{Km}$, des de la parada anteriorment efectuada. Tanmateix, es pot arribar directament fins aquí, remuntant des de Botarell la Riera de Riudecols.

En aquest recorregut, des de l'Estació de Botarell fins a les Voltes, s'haurà anat circulant per entre els materials quaternaris que cobreixen als miocènics. Uns i altres reblen la Depressió Prelitoral Catalana, on hem entrat a Botarell. Després, haurem entrat de nou a la Serralada Prelitoral Catalana, on ara ens trobem. Així, ara ens trobem entre afloraments dels materials esquistosos del Carbonífer, tot i que aquests es troben aquí recoberts per terrenys recents del Pleistocè i de l’Holocè.

En aquest indret, hi ha un antic Forn d'Obra. En aquest s'utilitzaven els terrenys argilosos que recobreixen parcialment al materials paleozoics del Carbonífer. El forn es troba mal conservat $\mathrm{i}$ forma part del Patrimoni Miner de la comarca del Baix Camp. 


\subsection{Parada 3. MINES DE COURE DE COLLBLANC, ERMITA DE PUIGCERVER, (terme de Riudecols, comarca del Baix Camp). (Full 455).}

Després de realitzar la parada anterior, cal retornar a la propera carretera N - 420, per tal de continuar cap a ponent. Així, aviat s'arribarà a la població de Riudecols. En arribar-hi, cal agafar el camí que es dirigeix cap a l'ermita de Puigcerver. Després de passar el Barranc del Mas d'en Cabré es troba el camí de la Mina de Collblanc. Aquí, farem una nova aturada, aproximadament a uns $3 \mathrm{Km}$ de la parada anterior.

En aquest recorregut, hem anat trobant afloraments dels materials paleozoics del Carbonífer. Així, fonamentalment, haurem trobat esquistos. També trobarem afloraments de les granodiorites del clap de l'Alforja. Aquests són els materials que apareixen a l'indret de la present aturada.

Efectivament, en aquest indret hi ha una mineralització filoniana, la qual es troba associada a una fractura E-W que talla les granodiorites del clap de I'Alforja. La mineralització filoniana és bàsicament cuprífera, amb presència de CALCOPIRITA, la qual es troba acompanyada d'abundant PIRITA. També hi ha gran nombre de minerals d'alteració com: GOETHITA (limonítica), ATZURITA i MALAQUITA, entre molts altres. Tanmateix hi ha indicis de CRISOCOL·LA.

Pel que fa a les explotacions mineres, cal dir que aquestes es troben pràcticament enrunades. (fotografia 2).

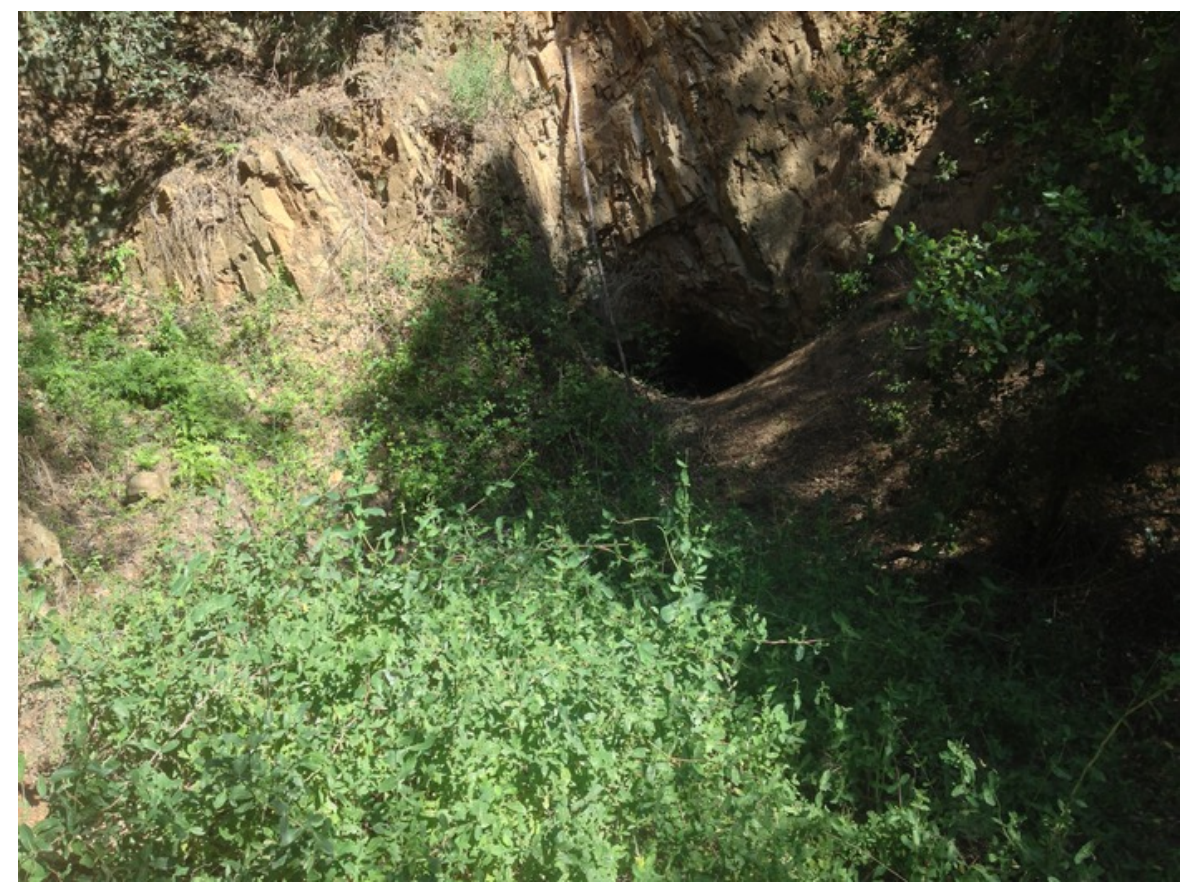

Fotografia 2. Restes de una galeria derrumbada, de les Mines de Collblanc. Riudecols 


\subsection{Parada 4. MINES DE COURE DEL BARRANC DE LES VALLS O MINES DE LES OLLES, CAMÍ DE PUIGCERVER A I'ALFORJA, (terme municipal de I'Alforja, comarca del Baix Camp). (Full 455).}

Després de realitzar la parada anterior, cal continuar pel camí que es dirigeix cap a l'ermita de Puigcerver i cap el Coll d'Alforja. Després de l'ermita, en trobar el camí que es dirigeix cap el poble de I'Alforja, caldrà agafar-lo, per tal de fer una aturada a les Mines de Coure del Barranc de les Valls (o del Barranc de les Olles), a les quals s'hi arriba per un sender (en uns 5 minuts), des del camí que baixa cap el poble de l'Alforja Així, haurem recorregut poc més de $4 \mathrm{Km}$, des de la parada anteriorment realitzada. Si s'escau, també es pot vindre directament des de Riudecols, per un trencall que surt per la dreta del camí a l'ermita.

En tot el recorregut, es van tallant els materials granítics del Clap de l'Alforja, i també els terrenys carbonífers, constituïts per esquistos i quarsites, sovint tallats per pòrfirs granítics. Així, tot el recorregut s'ha efectuat dintre de la Serralada Prelitoral Catalana.

Les antigues mines de coure de I'Alforja, es troben sobre unes mineralitzacions de sulfurs en skarns (MELGAREJO, 1992). Aquestes es troben al contacte entre nivells calcosilicatats del Carbonífer i el granits de I'Alforja. El mineral més abundant és la CALCOPIRITA, la qual va ésser motiu d'explotació.

Amb ella s'hi troben altres minerals, com els següents entre d'altres: ESFALERITA, GALENA, PIRROTINA, PIRITA, GAHNITA, ACTINOLITA, DIÒPSID, EPIDOTA, GRANATS, HEDENBERGITA, QUARS i TREMOLITA. També es poden trobar minerals d'alteració com: GOETHITA, ATZURITA, CERUSSITA, MALAQUITA i SMITHSONITA.

\subsection{Parada 5. PEDRERA DE LES IRLES. COLL NEGRE, (les Irles, terme municipal de Riudecols, comarca del Baix Camp). (Full 455).}

Després de realitzar la parada anterior, cal retornar cap el poble de Riudecols, per tal de continuar cap a ponent per la carretera nacional $N-420$. Així, per aquesta carretera, aviat s'arribarà al trencall del poblet de les Irles. Immediatament, la carretera nacional començarà a pujar cap el Coll Negre. Quasi en arribar-hi, trobarem un trencall (per l'esquerra) del vial que es dirigeix cap a les explotacions de pòrfirs granítics. Aquí, a la mateixa cruïlla, podem fer una nova aturada, a uns 4'5 $\mathrm{Km}$ de Riudecols i a uns $9 \mathrm{~km}$ de la parada anterior.

En aquest recorregut, hem anat trobant afloraments dels materials paleozoics esmentats a les aturades anteriors. Aquests materials pertanyen al carbonífer. Aquí, ara trobem un aflorament de pissarres negres, grafitoses i piritoses. Aquest aflorament, és el que ha donat lloc al topònim de la carretera.

Per altra banda, al Sud de la carretera es fa evident una gran explotació. En efecte, aquí s'extreuen pòrfirs granítics, per tal de ser emprats com a àrids per a la construcció. Per d'altra banda, cal dir que aquesta explotació te un gran impacte mediambiental, especialment visual, fent-se visible, per exemple, des d’Escornalbou. 


\subsection{Parada 6. MINES DEL MAS DEL MESTRE, (Cortiella, terme municipal de I'Alforja, comarca del Baix Camp). Full 455).}

Després de realitzar la parada anterior, cal continuar cap a ponent; però ara pel tram antic de la carretera nacional $\mathrm{N}-420$. Per aquesta carretera, en arribar al trencall que es dirigeix cap el Parc Eòlic del Collet dels Feixos, cal agafar-lo. Després, des del collet, es trobarà un camí que baixa cap el Mas del Mestre. En arribar prop del Mas del Boto, cal anar cap a Mas del Soi (o Mas del Covo). Prop d'aquesta casa es troben les antigues explotacions mineres, així com les escombreres. D'aquesta forma, des de la parada anterior, haurem efectuat un recorregut proper als $10 \mathrm{Km}$.

També es podria arribar aquí, des de l'ermita de Puigcerver (per on hem passat cap el recorregut i retorn de la PARADA 4). Així, caldria anar cap el Coll de Cortiella, per tal de baixar després pel Barranc de Cortiella, fins arribar al Mas del Boto. Així, des de l'ermita, hauríem efectuat un recorregut d'uns $5 \mathrm{Km}$, però per camins en no gaire bon estat de circulació.

Com als recorreguts anteriors, en aquest tram, hem anat trobant afloraments dels materials paleozoics del Carbonífer, esmentats a les aturades anteriors. Així, hem vist afloraments d'esquistos, fonamentalment.

En aquest indret hi ha unes interessants mineralitzacions filonianes (en part estratiformes associades a "sedex"), situades entre els materials del carbonífer. Així, es veuen fonamentalment unes mineralitzacions filonianes encaixades entre les pissarres del Carbonífer, molt properes a aflorament de granits. Els filons són de direcció $\mathrm{N}-80^{\circ}$ (i també $\mathrm{N}-110^{\circ}$ i $\mathrm{N}-$ $130^{\circ}$ ) amb uns 65 graus d'inclinació. Els minerals primaris més abundants són els següents: ESFALERITA, GALENA, MARCASSITA, PIRITA, HEMATITES, CALCITA, DOLOMITA, BARITINA I QUARS.

Com a minerals d'alteració, es troben també: GOETHITA, ANQUERITA, ATZURITA, MALAQUITA i SMITHSONITA. També hi ha presencia de dendrites de PIROLUSITA i de PSILOMELANA.

Per altra banda, també cal fer esment de mineralitzacions associades a skarn, al contacte amb les roques granítiques (amb les granodiorites). Així, en aquestes es fa palesa la presencia de GRANATS.

\subsection{Parada 7. CASALOT DEL COLL DE LA TEIXETA, (terme municipal de Duesaigües, comarques del Baix Camp). (Full 445).}

Després de realitzar la parada anterior, cal retornar al Collet dels Feixos i després al tram antic de la carretera nacional $N$ - 420. En trobar-la, ens convindrà anar cap a ponent, per tal d'arribar al Coll de Teixeta. Així, per arribar-hi, efectuarem un nou recorregut aproximat d'uns $10 \mathrm{Km}$, des de les Mines del Mas del Mestre. L'aturada la farem a la cruïlla del tram antic de la carretera nacional $\mathrm{N}-420$, amb la rotonda.

En aquest recorregut, hem continuat trobant afloraments dels materials paleozoics del carbonífer. Així, haurem vist afloraments de pissarres i d'esquistos, fonamentalment. Tot i així, en aquest indret, tocant al casalot, hi ha un interessant aflorament de roques intrusives. Es tracta d'unes riolites del Carbonífer. Així, en aquest lloc, es pot fer una bona observació d'aquestes roques, que també afloren una mica més amunt d'on som ara, per sota del Parc Eòlic del Mas de la Potra. 


\subsection{Parada 8. COLL DE LA TEIXETA, (termes municipals de Duesaigües i de Porrera, comarques del Baix Camp i del Priorat, respectivament). (Full 445).}

Després de realitzar l'aturada anterior, cal fer un breu recorregut (millor a peu) per la rotonda, per tal d'anar cap als sectors meridionals de la mateixa. Així, ens haurem desplaçat poc més de 150 metres.

Aquest indret es troba totalment situat dintre de la Serralada Prelitoral Catalana (és a dir: dintre del Sistema Mediterrani). Així, si be es veuen per arreu afloraments dels materials paleozoics del Carbonífer, que hem anat trobant als recorreguts anteriorment realitzats. Per d'altra banda, per sobre d'ells apareix uns nivells de gresos, que ja pertanyen al Triàsic Inferior (al Buntsandstein).

Així, en aquest indret es fa ben palesa la discordança entre els materials triàsics del Buntsandstein (constituïts per nivells de gresos i de lutites rogenques, que descansen sobre nivells de conglomerats quarsosos), i els materials del Carbonífer (formats per nivells de pissarres). Per d'altra banda, entre els materials del Buntsandstein es fa ben palesa l'erosió alveolar, amb bons exemples de la mateixa, situant-se entre els nivells dels gresos rogencs.

Igualment es fa palesa una falla, entre els materials paleozoics del Carbonífer i el mesozoics del Triàsic inferior (del Buntsandstein). Així, a la mateixa bora de la carretera es pot veure aquesta fractura, així com el seu mirall de falla i les estries. Aquestes darreres es fan molt paleses entre materials del Buntsandstein més durs, els corresponents als nivells de gresos $\mathrm{i}$ de conglomerats quarsosos.

La falla es fa notablement palesa a la vorera més meridional del coll. També, cal dir que aquest Coll de Teixeta, es troba totalment relacionat amb aquesta falla, de de direcció ENE - WSW, que tanmateix es fa palesa prop de Falset, prop del Coll Roig, a ponent d'on ara estem situats. (fotografies 3 i 4).

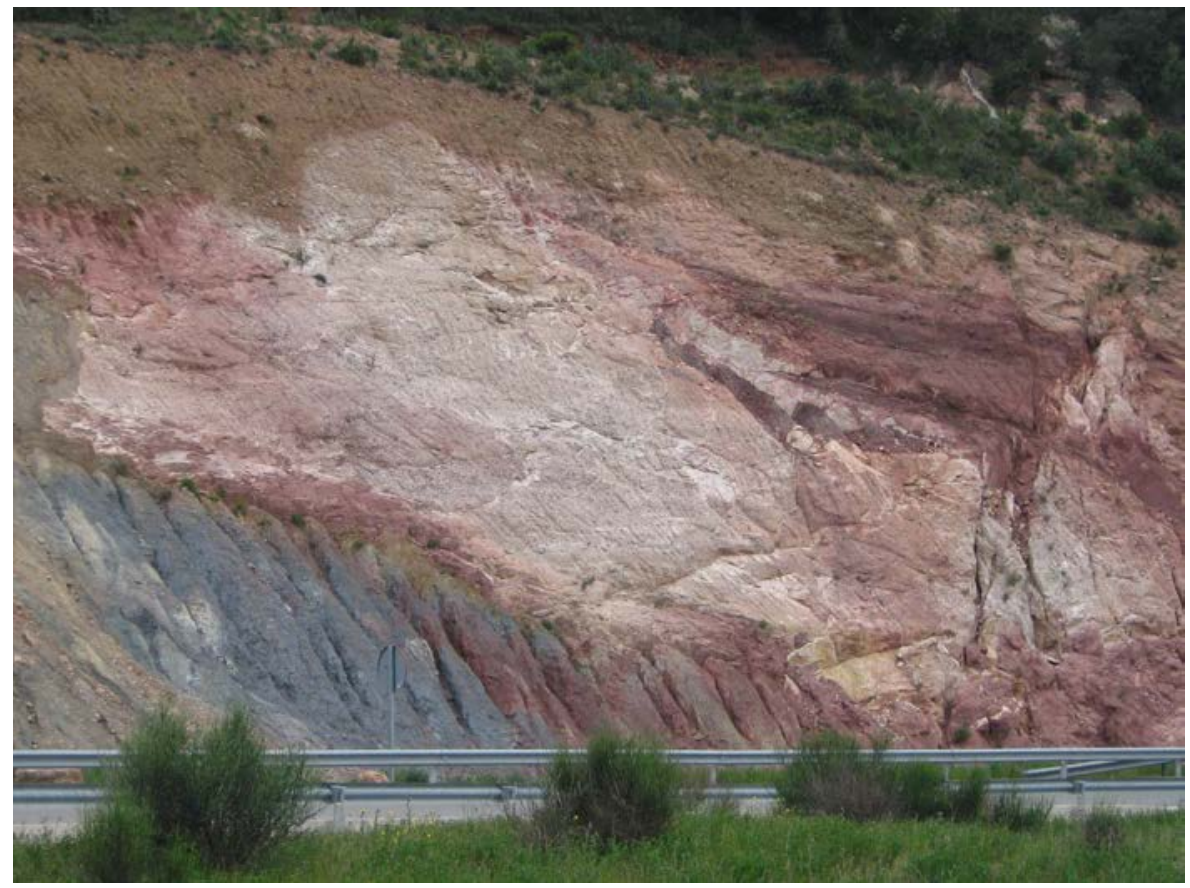

Fotografia 3. Un aspecte de la Falla del Coll de la Teixeta, entre els materials del Buntsandstein Inferior (nivells de conglomerats i gresos quarsosos) i les pissarres del carbonífer 


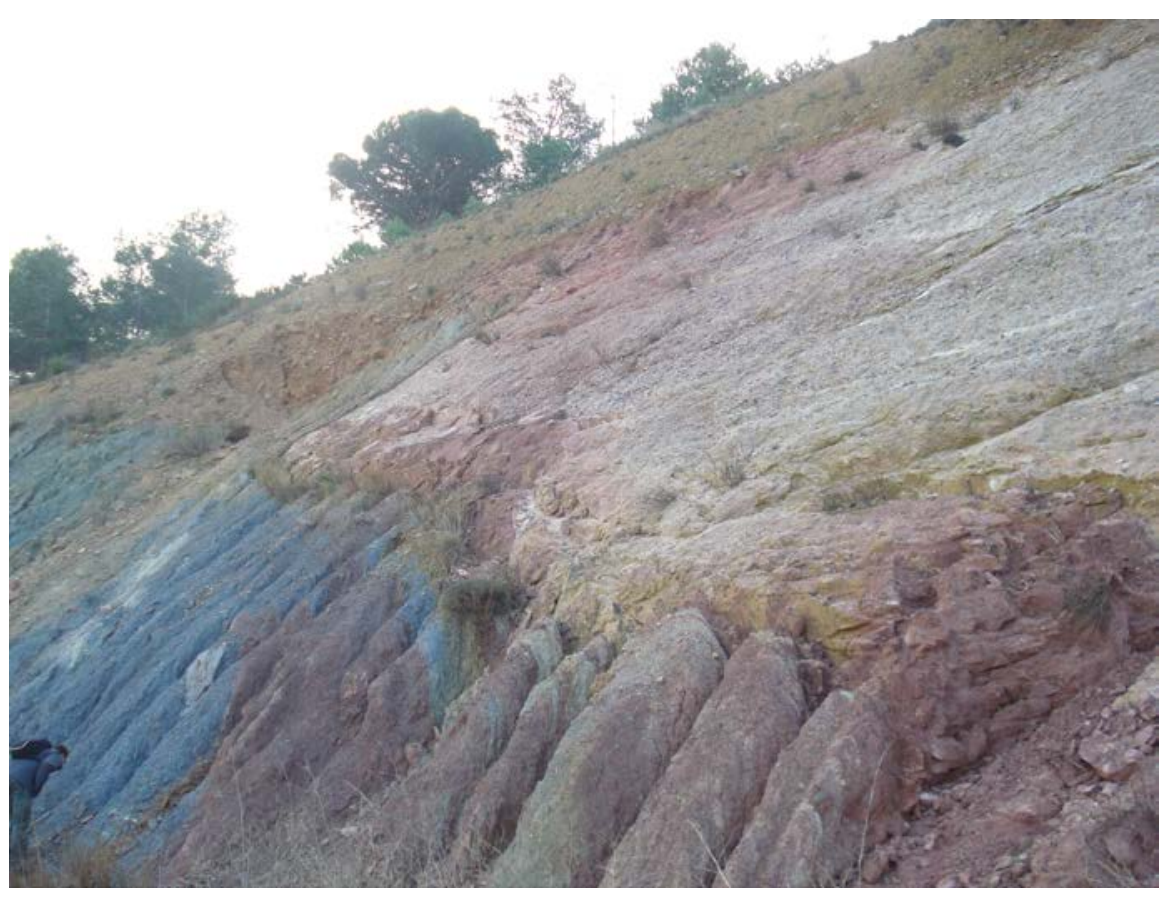

Fotografia 4. Un altre aspecte de la Falla del Coll de la Teixeta.

\subsection{Parada 9 - CONDICIONAL. MINA DE PLOM DE PRADELL, PARTIDA SOLANS, (terme de Pradell de la Teixeta, comarca del Priorat). (Full 445).}

Després de realitzar l'aturada anterior, cal fer un nou recorregut per la carretera $\mathrm{N}-420$, anant cap a ponent. Així, aviat es passarà pel coll de Pradell i quasi immediatament pel trencall que es dirigeix cap el poble de Pradell de la Teixeta. A menys d'un $\mathrm{Km}$ d'aquest trencall, es trobarà per la dreta de la carretera un camí que ascendeix ràpidament. En arribar prop de les torres d'alta tensió, es farà una nova aturada. Així, des de la parada anterior, haurem recorregut, aproximadament uns 3’5 $\mathrm{Km}$.

En aquest recorregut, hem començat a trobar afloraments dels materials triàsics. Inicialment, hem trobat els afloraments del Buntsandstein, situats al flanc meridional de la falla de la parada anterior. Després, haurem trobat els nivells carbonatats del Muschelkalk Inferior, situats estratigràficament per sobre dels trams rojos del Buntsandstein. Tot i així, ben prop del trencall de Pradell, s' han fet palesos afloraments dels trams argilosos i guixosos del Muschelkalk Mig, de tonalitats rogenques. Tot i així, ben aviat haurem trobat els nivells carbonatats del Muschelkalk Superior, especialment al camí ascendent cap a les torres d'alta tensió, per on farem aquesta aturada.

Malgrat això, on som ara, hem començat a trobar afloraments dels esquistos del paleozoic, del Carbonífer. El que ha passat és que hem sobrepassat una falla, precisament la que hem trobat a l'aturada anterior, sols que aquí al flanc meridional hi ha afloraments triàsics del Muschelkalk Superior (en lloc dels del Buntsandstein, que hi havia a l'aturada anterior). Mentre tant, al flanc septentrional continua havent els materials del Carbonífer.

En aquest indret hi ha una mineralització filoniana de $\mathrm{Pb}-\mathrm{Zn}-\mathrm{Ba}$, la qual es troba encaixada entre els materials paleozoics del carbonífer. Entre els minerals presents, cal fer esment dels següents: ESFALERITA, GALENA, PIRITA, CALCITA i BARITINA. Tanmateix, hi ha minerals d'alteració, com la GOETHITA. Tot i així, el minera més abundant és el sulfat de bari: la BARITINA. 


\subsection{Parada 10 - CONDICIONAL. LA GRAN COVA, (terme municipal de Pradell de la Teixeta, comarca del Priorat). (Full 445).}

Després de realitzar l'aturada anterior, cal fer un nou recorregut per la carretera $\mathrm{N}-420$, anant cap a ponent. Així, aviat s'arribarà a les immediacions de l'antic $\mathrm{Km} \mathrm{846} 4$. Prop d'aquest indret, podem fer una nova aturada, si s'escau, a poc més de $1^{\prime} 5 \mathrm{Km}$ de la parada anteriorment efectuada.

En aquest recorregut, en anar baixant cap a la carretera nacional, hem trobat els afloraments dels materials esmentats a l'aturada anterior. Així, hem vist els nivells de calcàries i de dolomies del Muschelkalk Superior. Aquests són també els materials que afloren a l'indret on ara ens trobem. Així, en aquest indret, hi ha una gegantina cova, la qual es troba sobre els afloraments dels materials carbonatats esmentats anteriorment.

\subsection{Parada 11. ANTIGA FÀBRICA DE GUIX, (terme municipal de Pradell de la Teixeta, comarca del Priorat). (Full 472).}

Des de la parada anterior cal retrocedir a Pradell de la Teixeta, així, ens caldrà seguir inicialment la carretera nacional N-420. Més endavant, trobarem la cruïlla d'on surt la carretera local que es dirigeix cap el poble, la TV - 3223. Ben aviat trobarem l'antiga fàbrica de guix situada a la vora de la carretera. Aquí farem una nova aturada, després de recórrer uns 2' $5 \mathrm{Km}$ des l'aturada anterior.

En aquest recorregut, hem anat trobant afloraments dels materials carbonatats del Muschelkalk Superior; així veurem nivells de calcàries i de dolomies. Després, prop de l'indret de l'aturada, es fan palesos els afloraments dels materials rogencs del Muschelkalk Mig, amb trams d'argiles i de guixos, fonamentalment. Aquests darrers són ja els materials que apareixen prop de l'indret de l'aturada.

En aquest lloc es treballaven els materials guixosos extrets a la guixera de la parada anterior, per tal d'obtenir guix industrial per a la construcció. A l'actualitat (a l'igual que la guixera) es troba totalment aturada.

Finalment, cal dir que aquest element industrial forma part del nostre patrimoni miner, mereixent una certa protecció.

\subsection{Parada 12. GUIXERA DE PRADELL DE LA TEIXETA, (terme municipal de Pradell de la Teixeta, comarca del Priorat). (Full 472).}

Després de fer l'aturada anterior, cal seguir l'itinerari cap a ponent, per la carretera local TV 3223, la qual es dirigeix cap el proper poble de Pradell de la Teixeta. En arribar al poble, cal travessar-lo, per tal de continuar el recorregut cap a la Torre de la Fontaubella. Més endavant, després de sobrepassar Pradell, a uns $2 \mathrm{Km}$ de la població, caldrà continuar per un camí (cap a I'esquerra), el qual arriba fins a les antigues guixeres, on farem una nova aturada d'aquest itinerari. (fotografia 5). 


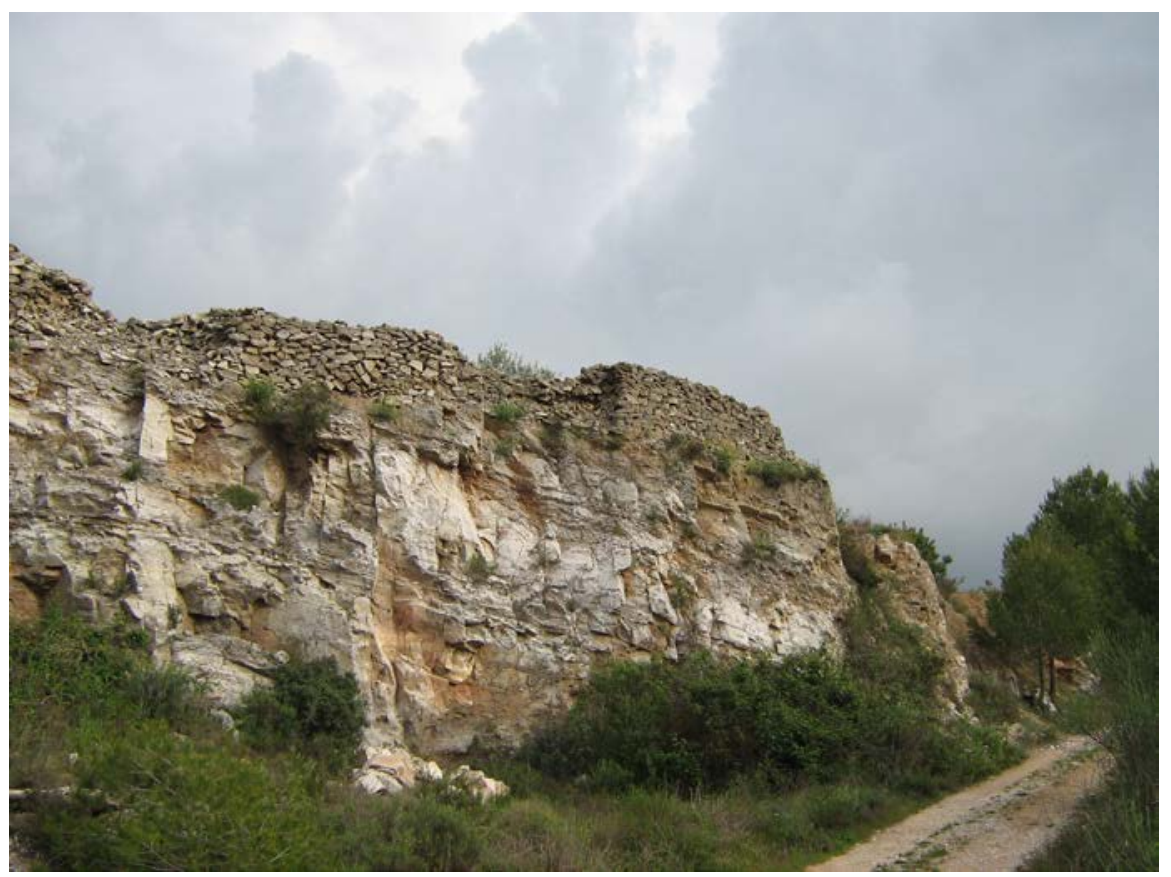

Fotografia 5. Un aspecte de les antigues explotacions de guix, de Pradell de la Teixeta. Es troben situades sobre un aflorament dels nivells de guixos del Muschelkalk Mig

Un aspecte del Parc Eòlic de la Serra de la Torre de la Fontaubella, situat per sobre de Pradell de la Teixeta, vist des del castell d'Escornalbou

En aquest recorregut, hem anat travessant afloraments dels materials carbonatats (calcaris $\mathrm{i}$ dolomítics), els quals pertanyen al Muschelkalk Inferior. Tanmateix, hem trobat afloraments de nivells argilosos del Muschelkalk Mig. Uns i altres pertanyen al Triàsic Mig de la Serralada Prelitoral Catalana, per on estem ara situats.

En aquest lloc hi ha una antiga explotació dels nivells de guixos triàsics (del Muschelkalk Mig). A I'actualitat l'explotació de la guixera es troba totalment aturada, i sovint s'utilitza per a tirar-hi runes i residus. Els materials extrets en aquest indret $s^{\prime}$ utilitzaven com a matèria prima de la fàbrica de guix que hem vist a la parada anterior. (fotografia 5).

Per altra banda, en aquest indret hi ha un antic Forn de Guix. Aquí s'empraven els nivells de guix explotats a la pedrera, abans d'utilitzar-se la fàbrica de guix que hem vist a l'aturada anterior. En relació a aquest indret, cal dir que constitueix un important element del Patrimoni Miner de la Comarca del Priorat. Alhora, en funció de la seva tipologia, es també un important element del Patrimoni miner de Catalunya. (fotografia 6). 


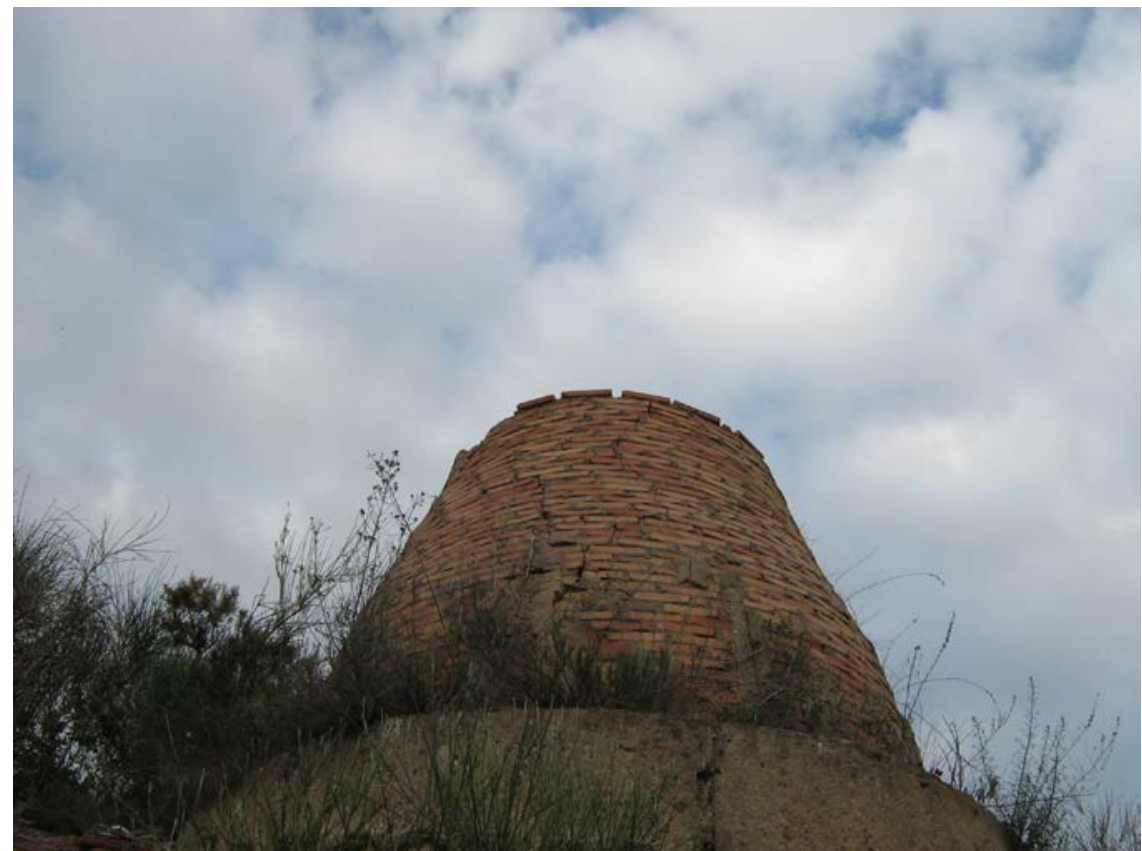

Fotografia 6. Un aspecte de I'antic Forn de Guix. Pradell de la Teixeta

Finalment, cal dir que aquesta guixera es troba situada sota d'un dels parcs eòlics de la zona (el de la Serra de la Fontaubella) i molt fàcilment es pot sentir la fresa de les aspes al rodolar. (fotografia 7).

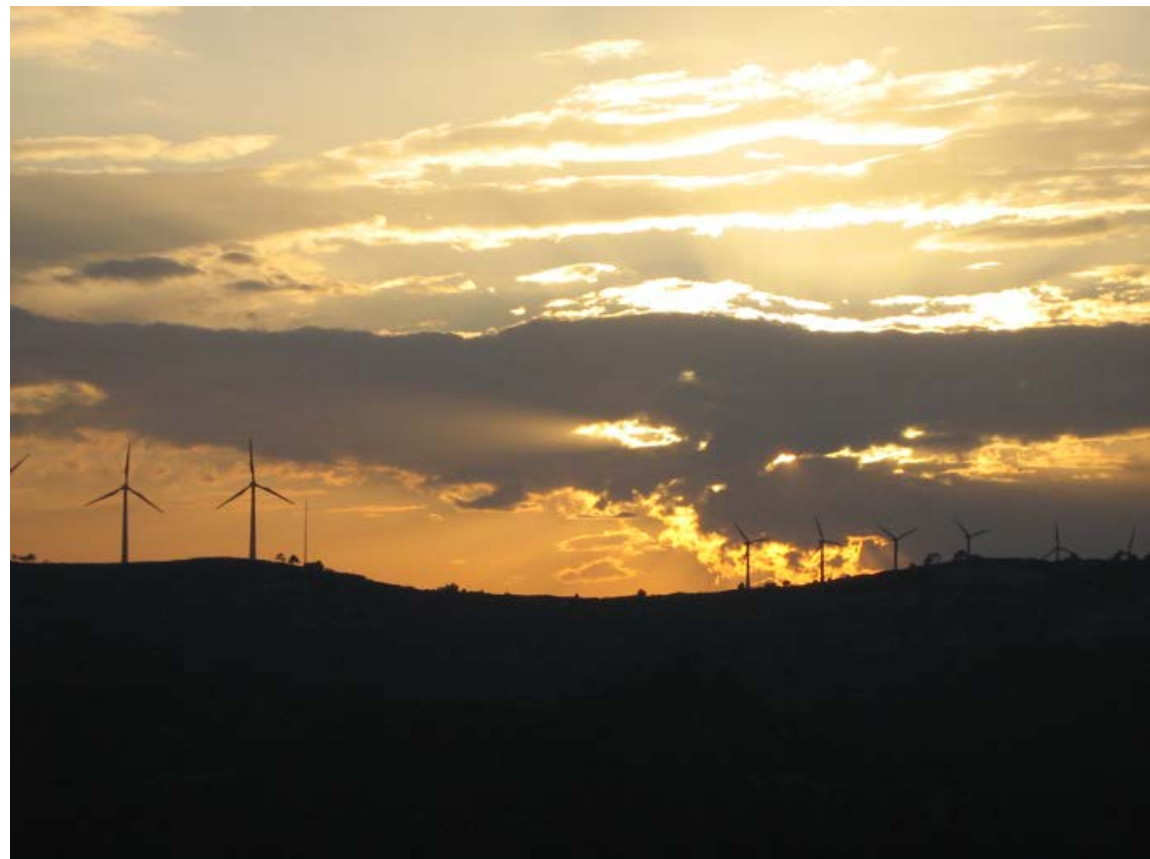

Fotografia 7.Un aspecte del Parc Eòlic de la Serra de la Torre de la Fontaubella, situat per sobre de Pradell de la Teixeta, vist des del castell d’Escornalbou 
En aquest indret finalitza el recorregut de l'itinerari

\section{Bibliografia}

GUIMERÀ, J. et altri (1992).- Geologia (II), Història Natural dels Països Catalans, Vol. 2, 547 pag. Enciclopèdia catalana, S.A., Barcelona.

IGME (1974a).- Mapa Geológico de España a Escala 1:50.000 (2a Sèrie). Full i Memòria nº 445 (Cornudella). Inst. Tecnológico y GeoMinero de España. Minist. Indus. Ener. Madrid.

IGME (1974b).- Mapa Geológico de España a Escala 1:50.000 (2a Sèrie). Full i Memòria nº $\underline{472}$ (Reus). Inst. Tecnológico y GeoMinero de España. Minist. Indus. Ener. Madrid.

MATA-PERELLÓ, J.M. (1991).- Els Minerals de Catalunya Arxius de la Secció de Ciències, Vol XCIII, 444 pag. Institut d’Estudis Catalans, Barcelona.

MATA-PERELLÓ, J.M. (1994).- Itinerari geològico-mineralògic entre Reus (Baix Camp) i la Venta del Pubill (priorat). Revista Xaragall, $n^{\circ} 34$, pp. $29-35$. Manresa.

MATA-PERELLÓ, J.M. (1995).- Apunts per a un itinerari geològico-mineralògic entre l'Alforja (Baix Camp) i Porrera (Priorat) / modificacions a una excursió efectuada el dia 11 de febrer del 1995. Inèdit, 8 pàgines. Manresa.

MATA-PERELLÓ, J.M. i SANZ BALAGUÉ, J. (2014a).- Recorregut de recerca geològica i mineralògica per les comarques del Baix Camp i del Priorat: des de Montbrió del Camp i Riudecanyes a Escornalbou, Argentera, Duesaigües i al Coll de Teixeta. Inèdit. 14 pàgines. Manresa.

MATA-PERELLÓ, J.M. i SANZ BALAGUÉ, J. (2014b).- Recerca geològica i mineralògica per les comarques del Baix Camp i del Priorat: des del Coll de Teixeta a Porrera, Cornudella del Montsant i a Siurana de Prades. Inèdit. 10 pàgines. Manresa.

MELGAREJO I DRAPER J.C. (1992).- Estudio geológico y metalogenético del paleozoico del sur de las Cordilleras Costeras Catalanas. Memórias del Instituto Tecnológico y Geo-Minero de España, tomo 103, 605 páginas. Madrid.

RIBA ARDERIU, O. Et altri. (1976).- Geografia física dels Països Catalans. Edit Ketres. Barcelona. 